Olga Otłowska ${ }^{1}$, Mirosław Wachowiak ${ }^{2}$

Magdalena Śliwka-Kaszyńska ${ }^{1}$, Grzegorz Trykowski ${ }^{3}$

1) Katedra Chemii Organicznej, Politechnika Gdańska

2) Zakład Konserwacji i Restauracji Sztuki Nowoczesnej, UMK Toruń

3) Pracownia Analiz Instrumentalnych, Wydział Chemii, UMK Toruń

\title{
Żółte barwniki organiczne w XIX-wiecznych farbach Jana Matejki - identyfikacja substancji barwiących, nośników oraz wypełniaczy
}

W $\begin{aligned} & \text { aturalne barwniki organiczne są komponentami wielu obiektów dzie- } \\ & \text { dzictwa kulturowego. Identyfikacja substancji barwiących obecnych }\end{aligned}$ w farbach historycznych dostarcza istotnych informacji dla szerokiego grona specjalistów zajmujących się dziełami sztuki. Znajomość składu barwników pomaga nie tylko w określaniu czasu powstania dzieła, czy też jego pochodzenia, ale także w potwierdzeniu autentyczności i w końcu opracowaniu odpowiedniej i efektywnej procedury konserwatorskiej ${ }^{1}$. Wiedza dotycząca materiałów malarskich jest niezbędnym narzędziem pracy konserwatora, a poznanie składu chemicznego substancji barwiących pozwala na rozpoznanie rodzaju i źródła barwnika stosowanego przez artystę. Określenie nośnika barwników oraz wypełniaczy zastosowanych w lakach, rozszerza charakterystykę badanej farby, stanowiąc istotną informację natury technologicznej, czasami także wspomagająca datowanie. Znajomość do-

1 I. Karapanagiotis, E. Minopoulou, L. Valianou, S. Danilia, Y. Chryssoulakis, Investigation of the colourants used in icons of the Cretan School of iconography, „Anal. Chim. Acta” 2009, 647, s. 231-242. 
kładnego składu substancji barwiących w farbach artystycznych umożliwia lepszą ocenę ich odporności na środki stosowane m.in. do oczyszczania z zabrudzeń lub usuwania werniksów w trakcie konserwacji. Pełna identyfikacja umożliwia niejednokrotnie precyzyjne odtworzenie ich w laboratorium, co pozwala uzyskać bezcenny materiał do przeprowadzenia badań starzeniowych. Postarzone próbki tak odtworzonych farb historycznych pozwalają wykonać dalsze systematyczne analizy np. prób odporności na różnego typu rozpuszczalniki. Stanowia ponadto bezcenny materiał wyjściowy do określania przemian chemicznych towarzyszących starzeniu się substancji barwiących. Ułatwia to identyfikację oryginalnych materiałów historycznych, w których niejednokrotnie barwnik uległ już przemianom w stosunku do materiału wyjściowego. Dają także podstawę do oceny zmian barwy w wyniku tychże przemian. Jest to szczególnie istotne w przypadku tych barwników, które są bardziej podatne na procesy degradacji. Potwierdzaja to drastyczne przypadki optycznych zmian występujących na obrazach XVII-wiecznych malarzy. W wielu ich obrazach zielenie były często budowane poprzez wierzchni żółty laserunek spodniego monochromatycznego opracowania niebieskiego. W wyniku blaknięcia żółcieni listowie w części z nich ma obecnie zamiast koloru zielonego intensywną barwę błękitną* Inny wymowny przykład blaknięcia barwnika w sposób silnie zakłamujący pierwotną kompozycję to użycie wprowadzonego w latach 70. XIX wieku czerwonego barwnika syntetycznego - eozyny - przez van Gogha. Na obrazach z cyklu Kwitnace br:oskwinie z 1888 roku, w wyniku utraty barwy eozyny, tytułowe drzewa maja obecnie kolor biały. Sugeruje to zupełnie inne ich gatunki kwitnące na biało, np. jabłka bądź wiśnie². Innym aspektem, obok samego barwnika, mającym istotny wpływ na sposób i tempo powstania ewentualnych zmian w barwie farb opartych na lakach, jak i ich reakcji na działania konserwatorskie, stanowi również często specyficzne

2 A Closer Look. Technical and Art.-Historical Studies on Works by Van Gogh and Gauguin, Amsterdam, 1991, ed. C. Peres, L. van Tilborgh, M. Hoyle, s. 58-59, obecna na omawianych obrazach Róźowy sad, Kwitnace brzoskwinie, Biały sad, wszystkie z 1888 roku z Van Gogh Museum, Amsterdam, na podstawie listów znana jest nazwa producencka Laque géranium, tamże s. 58; w Van Gogh's Studio Practice, M. Vellekoop, M. Gedldof, E. Hendricks, L. Jansen, A. Tagle, ed. Szerzej jest omówione użycie eozyny również na innych obrazach artysty, s. 268-89. 
spoiwo. Zwykle podkreśla ono transparentność i ułatwia zasychanie farby. Często ma ono charakter bardziej żywiczny niż w przypadku pigmentów nieorganicznych. Niemniej zagadnienia spoiwa nie sa przedmiotem niniejszych rozważań i nie były dotychczas dla próbek farb Matejki objęte gruntownymi badaniami.

Identyfikacja poszczególnych barwników organicznych na obiektach malarskich, zwłaszcza w przypadku barwników żółtych (barwniki czerwone są częściej i dokładniej analizowane) jest niezwykle rzadka. W przypadku badań obrazów impresjonistów z National Gallery w Londynie, wskazano na obecność żółtego laku osadzanego na związkach glinu na jednym z obrazów Claude'a Monet. Natomiast na obrazie Cézanne'a stwierdzono żółty lak osadzany na związkach glinu i kredzie, bez dalszych rozróżnień występujących substancji barwiących ${ }^{3}$. Wśród blisko trzydziestu przykładów identyfikacji barwników występujących na dziesięciu obrazach Aleksandra Gierymskiego ${ }^{4}$ barwnik żółty wykryto tylko w trzech przypadkach. W próbce warstwy malarskiej z Damy rokokowej (1881) zidentyfikowano ramnazynę wskazująca, że prawdopodobnym źródłem barwnika były owoce krzewu z rodziny Rhamnus - szakłaku lub kruszyny. Z kolei w próbkach pobranych z obrazów Paź wenecki (1884) i Motyw z. Placu Wittelsbachów (ok. 1889) zidentyfikowano kwercetynę oraz kemferol, sugerujące jako źródło barwnika korę północnoamerykańskiego dębu kwercytrynowego ${ }^{5}$. Obecnie prowadzone badania w ramach projektu Nowe pigmenty XIX w. ${ }^{6}$ wykazały, iz ponad jedna czwarta obrazów XIX-wiecznych artystów obejmuje swą paletą żółte barwniki. Często występuje więcej niż jeden ich rodzaj na danym obrazie.

3 D. Bomford, J. Kirby, J. Leihton, A. Roy, Art in the making. Impressionism, London 1990, s. 200-201.

4 Patrz: E. Doleżyńska-Sewerniak, W. Nowik, W. Sanyová, Badania barwników organicznych wchodzacych w sketad farb laserunkonych obrazón Aleksandra Gierymskiego z. lat 1870-1901, [w:] Badania technologii i technik malarskich, konserwacja dziet sæ̨tuki, kopia. Ksiega pamiatkowa z. okazji jubileuszu 50-lecia pracy dedykowana prof. dr art. kons. Józefowi Flikowi, Toruń 2007, oraz: E. Doleżyńska-Sewerniak, Materialy malarskie i technika w obrazach olejnych Aleksandra Gierymskiego, Toruń 2010, s. 510-511.

5 E. Doleżyńska, Materiały malarskie..., jako źródło tej substancji błędnie sugerowane są drzewa z rodziny bukowatych, ibidem, s. 510 .

${ }^{6}$ Nowe Pigmenty XIX wieku, projekt NCN w ramach Sonaty, 2012/05/D/HS2/03385, kierownik projektu M. Wachowiak. 
Grupe te powiększyć moga jeszcze wnikliwsze badania prawdopodobnych mieszanin pigmentów nieorganicznych i barwników oferowanych przez producentów jako jeden gotowy kolor, który w identyfikacjach często rozpoznawany jest tylko jako pigment, bez swego organicznego komponentu. Badania żółtych laków obecnych na obrazach XIX-wiecznych maja jeszcze jeden istotny i dotąd również nierozpoznany aspekt badawczy, a mianowicie identyfikację wprowadzanych od połowy XIX wieku barwników syntetycznych, które mogą stanowić w przyszłości ważne narzędzie datujące ze względu na precyzyjne daty ich odkryć.

Izolacja i identyfikacja barwników zawartych w farbach artystycznych jest często skomplikowana i pracochłonna. Farby w swoim składzie zawierają bowiem nie tylko właściwe substancje barwiące, ale także spoiwa malarskie i inne dodatki, które utrudniaja pełną analizę substancji barwiących. Ponadto, procedura pobierania próbki farby malarskiej z obrazu jest znacznie mniej elastyczna niż w przypadku np. włókien tekstylnych. Próbki farb pobierane są w ilościach mikrogramowych, niewystarczających często do przeprowadzenia spektroskopowej analizy Magnetycznego Rezonansu Jadrowego (NMR), która dostarczyłaby dokładnych informacji o budowie strukturalnej związku odpowiedzialnego za barwę. Co więcej, część naturalnych barwników organicznych nie jest już dostępna na rynku, a co za tym idzie, brak jest odpowiednich wzorców ${ }^{7}$. Oprócz tego podejmowane próby rekonstrukcji substancji barwiących, pozyskiwanych głównie z roślin, a następnie łączenie ich ze spoiwem, nie gwarantuja pełnego odtworzenia dość skomplikowanego składu farby. Co więcej, pozyskiwanie barwnika, jak i dalsza procedura wytwarzania farby prowadzona była na przestrzeni wieków

O wzorcach laków z rekonstruowanych na podstawie historycznych recept i o ich wstępnej identyfikacji patrz: M. Górzyńska, J. Olszewska-Świetlik, Wybrane źótte laki. Rekonstrukeja technologiczna, „Biuletyn Konserwatorów Dzieł Sztuki” 2002, vol. 13, no. 1-2 (48-49), s. 26-33; A. Dobrowolski, Chemia i technologia laków i pigmentów, Warszawa, 1953; J. Olszewska-Świetlik, T. Szymczak, J. Olszewska-Świetlik, Wybrane rodzaje źóttych, brazonych $i$ czerwonych lakón organicznych - wstępna metodyka badawcza; „AUNC. Zabytkoznawstwo i Konserwatorstwo”, XLII, Toruń 2011, s. 297-340; P. Mindykowska, J. Olszewska-Świetlik, Rekonstrukcja technologicznna $i$ badania nieinwasyjne uybranych czerwonych lakón organicznych, praca drukowana w obecnym tomie na podstawie pracy magisterskiej: P. Mindykowska, Zagadnienia technologii $i$ badan mybranych czerwonych laków organicznych, Torun 2014, wydruk komputerowy, Archiwum UMK, pod kierunkiem dr hab. Justyny Olszewskiej-Świetlik, prof. UMK, wraz z autorami dodatkowych analiz. 
na niezliczone sposoby ${ }^{8}$. Problematyka identyfikacji barwników z próbek farb jest bardzo rozległa. Zasadnym wydaje się więc konieczność opracowania optymalnej i uniwersalnej metodyki ich izolacji oraz identyfikacji.

Naturalne barwniki organiczne pozyskiwane z roślin, owadów czy skorupiaków, ze względu na swoje pochodzenie, w większości występują w formie glikozydów (połączeń z jednostkami cukrowymi). Należy przy tym pamiętać, że za barwę jednego naturalnego barwnika odpowiadać może kilka substancji o bardzo zbliżonych lub znacznie różniących się właściwościach fizykochemicznych, co powinno być uwzględnione w trakcie opracowywania metod ich ekstrakcji. Zdarza się również, że skład substancji barwiących zależy od miejsca pochodzenia surowca. Doskonałym przykładem takich subtelnych różnic jest koszenila - barwnik pozyskiwany z owadów z nadrodziny czerwców, którego skład różni się w zależności od środowiska życia owadów9 ${ }^{9}$ Naturalne barwniki, oprócz samych substancji barwiących, mogą w swoim składzie zawierać i inne związki organiczne, takie jak białka, lipidy, cukry itp., które utrudniają ich identyfikację. Ekstrakcja barwników z surowców naturalnych oraz proces produkcji laków może powodować częściowy ich rozkład, na przykład hydrolizę jednostek cukrowych. Identyfikacja substancji barwiących zachowanych w niezmienionej formie, jest niezwykle ważnym elementem podczas określania źródła ich pochodzenia. Co więcej, pozwala odróżnić barwniki naturalne od ich syntetycznych analogów, a to z kolei ułatwi orzekanie o autentyczności historycznych dzieł sztuki oraz wspomoże ich datowanie. Izolacja substancji barwiących z tak skomplikowanych matryc, jakimi sa farby artystyczne, jest zadaniem dość trudnym. Naturalne barwniki organiczne w farbach istnieja bowiem w postaci tak zwanych laków, będących kompleksami substancji barwiących z metalami osadzonymi na nośnikach nieorganicznych ${ }^{10,11}$.

8 Patrz P. Mindykowska, J. Olszewska -Świetlik, Rekonstrukcja technologiczna...

9 E.S.B. Ferreira, A.N. Hulme, H. McNab, A. Quye, The natural constituents of historical textile dyes, „Chem. Soc. Rev.” 2004, 33, s. 329-336.

10 CPC - C09B - 2014.06. Dostępny w Internecie: http://www.uspto.gov/web/patents/ classification/cpc/pdf/cpc-definition-C09B.pdf

11 J. H. Hofenk de Graaff, The Colorful Past: Origins, Chemistry and Identification of Natural Dyestuffs, „Archetype Publications” 2004, s. 17-18; Artists'Pigments. A Handbook of their History and Characteristics, red. R. L. Feller, vol. 1, 1986, s. 109-142. 
W celu identyfikacji substancji barwiących należy najpierw wyizolować je z laku oraz ze spoiwa malarskiego, tak aby nie spowodować zmian w ich pierwotnej strukturze ${ }^{12}$. Tradycyjna metoda ekstrakcji substancji barwiących z farb i laków opierała się na zastosowaniu mieszaniny metanolu z wodnymi roztworami silnych kwasów nieorganicznych, takich jak kwas siarkowy (VI) lub kwas solny oraz prowadzeniu procesu w wysokiej temperaturze ${ }^{13},{ }^{14}$. Warunki te miały ułatwić hydrolizę kompleksów typu metal-barwnik. Niestety, silne kwasy mineralne hydrolizuja nie tylko kompleks metal-barwnik, co jest reakcją pożądaną, ale powodują również hydrolizę glikozydowych fragmentów cząsteczki barwnika, co pozwala na identyfikację jedynie samego aglikonu (rys. 1).

Kolejnym negatywnym efektem stosowania silnych kwasów w procesie uwalniania barwników z laku, jest dekarboksylacja (np. pseudopurpuryny do purpuryny) czy też dehydratacja grup hydroksylowych (np. dehydratacja brazyleiny) ${ }^{15}$. Reakcje uboczne towarzyszące hydrolizie próbki laku powoduja zmianę pierwotnej struktury substancji barwiących. W związku z tym identyfikacja rzeczywistego składu barwnika staje się niemożliwa. Dlatego też nadal poszukuje się efektywnych i łagodnych odczynników umożliwiających uwolnienie substancji barwiących z laku. Ostatnie badania wykazały wysoką efektywność procesu ekstrakcji przy zastosowaniu kwasu fluorowodorowego (HF) jako łagodnego odczynnika izolującego substancje barwiące z laków ${ }^{16}$. Kwas fluorowodorowy dzięki niskiej kwasowości oraz właściwościom kompleksującym jony metali, skutecznie izoluje substancje barwiące z kompleksu, nie powodując przy tym rozkładu wiązań glikozydowych

12 J. Sanyova, J. Reisse, Development of a mild method for the extraction of anthraquinones from their aluminum complexes in madder lakes prior to HPLC analysis, "Journal of Cultural Heritage" 2006, 7, s. 229-235.

$13 \mathrm{~J}$. Wouters, High performance liquid chromatography of anthraquinones: analysis of plant and insect extracts and dyed textiles, „Stud. Conserv.” 1985, 30, s. 119-127.

14 S. Halpine, An improved dye and lake pigment analysis method for high-performance liquid chromatography and diode array detector, „Stud. Conserv.” 1996, 41, s. 76-94.

15 I. Boldizsar, Z. Szucs, Zs. Fuzfai, I. Molnar-Perl, Identification and quantification of the constituents of madder root by gas chromatography and high-performance liquid chromatography, ,J. Chromatogr. A" 2006, 1133, s. 259-274.

$16 \mathrm{~J}$. Sanyova, Mild extraction of dyes by bydrofluoric acid in routine analysis of historical paint micro-samples, „Microchim. Acta.” 2008, 162, s. 361-370. 
ani innych niepożądanych reakcji. Jeszcze wyższą wydajność procesu izolacji barwnika ze spoiwa malarskiego uzyskuje się poprzez zastosowanie fal ultradźwiękowych lub mikrofal.

W niniejszym opracowaniu przedstawiona została procedura analityczna do izolacji i identyfikacji czterech żółcieni organicznych z tubek farb historycznych pochodzących z pracowni Jana Matejki, oznaczonych odpowiednio symbolami Matejko 13, 14, 15 i 16. Tubki obejmują farby firmy Richard Ainè, Paris (pierwotnie Eduard, na co wskazują częściowo zachowane etykiety papierowe na tubach, następnie Mulard, o czym informuja wytłoczenia na zakrętkach niektórych tub) ${ }^{17}$. Zostały one nabyte najprawdopodobniej w sklepie optycznym Biasiona w Krakowie. Zarówno częściowo zachowane etykiety, jak i lista materiałów malarskich zakupionych przez Matejkę w latach 1880-1883 w tymże sklepie ${ }^{18}$ umożliwia łączyć poszczególne farby z ich francuską nazwą handlowa. Nazwa ta, co częste w XIX w., nie zawsze pokrywała się w pełni z sugerowanym przez producenta składem. Zebrane informacje posłużą więc nie tylko analizie materiałów malarskich Matejki, ale i interpretacji źródeł zachowanych, np. w postaci historycznych katalogów farb oferowanych przez francuskie firmy. Farby z tub, jako materiał badawczy, są szczególnie cenne. Umożliwiaja analizę historycznych barwników i pigmentów w stanie czystym, niezmieszanym (o ile nie stanowia gotowej wprowadzonej do obrotu mieszaniny producenckiej), w związku z czym wynik jest dużo bardziej precyzyjny. Tak uzyskane dane pozwalają również na pełniejsze rozumienie analiz pomiarów wykonanych dla obrazów, na których kolor najczęściej występuje w mieszaninie i widmo uzyskane do interpretacji jest dużo bardziej złożone.

Do izolacji barwników ze spoiwa malarskiego zastosowano metodę z użyciem kwasu fluorowodorowego, wspomaganą dodatkowo falami ultradźwiękowymi. W celach porównawczych zastosowano również ekstrakcję z zastosowaniem kwasu solnego. Identyfikację i rozdzielenie substancji barwiących

17 M. Wachowiak, 19th century paints of Richard Ainé used by Jan Matejko (1838-1893), Lasers in the Conservation of Artworks VIII, Ed. R. Radvan et al., London 2011; M. Wachowiak, A. Klisińska-Kopacz, Issues of Jan Matejko Painting Technique, Interdisciplinary Research of the Works of Art, ed. J. Olszewska-Świetlik et al., Torun 2012.

18 Maszynopis stanowiący odpis oryginału przechowywany jest w Domu Matejki w Krakowie. 
przeprowadzono z zastosowaniem wysokosprawnej chromatografii cieczowej (HPLC) z detekcją UV/vis (DAD) sprzężoną ze spektrometrią mas (MS).

Nośniki laków oraz wypełniacze określono badając skład pierwiastkowy z użyciem spektrometru XRF oraz na przekrojach poprzecznych badanych w skaningowym mikroskopie elektronowym (SEM) sprzężonym z energodyspersyjnym spektrometrem rentgenowskim (EDX).

\section{Metoda ekstrakcji}

\section{z zastosowaniem kwasu fluorowodorowego}

W celu rozpulchnienia spoiwa badanej farby do badanej próbki $(\sim 0.2 \mathrm{mg})$ dodano $100 \mu \mathrm{L}$ chlorku metylenu (DCM) i poddano działaniom fal ultradźwiękowych przez 15 min, następnie rozdrobniono mechanicznie próbkę i pozostawiono na kolejne $5 \mathrm{~min}$ w łaźni ultradźwiękowej. Po tym czasie rozpuszczalnik odparowano $\mathrm{w}$ atmosferze azotu w temperaturze $40^{\circ} \mathrm{C}$. Do próbki zawieszonej w $100 \mu \mathrm{L}$ mieszaniny dimetulosulfotlenku: acetonitrylu: metanolu (DMSO/ACN/MeOH) $(1 / 1 / 1, v / v / v)$ dodano $50 \mu \mathrm{L} 4 \mathrm{M}$ wodnego roztworu HF i poddano działaniom fal ultradźwiękowych przez $60 \mathrm{~min}$, a następnie pozostawiono na $5-12 \mathrm{~h}$ bez dostępu światła w temperaturze pokojowej. Po tym czasie próbki poddano działaniom fal ultradźwiękowych przez $10 \mathrm{~min}$ i odwirowano (9000 rpm, 3 min). Roztwór znad osadu oczyszczano z nadmiaru kwasu fluorowodorowego i jonów fluorkowych z zastosowaniem ekstrakcji do fazy stałej (SPE). Otrzymany ekstrakt substancji barwiących odparowywano w strumieniu azotu w temperaturze $40^{\circ} \mathrm{C}$. Sucha pozostałość rozpuszczono w mieszaninie DMSO/ACN/Me$\mathrm{OH}(1 / 1 / 1, v / v / v)$, poddano działaniom fal ultradźwiękowych przez $5 \mathrm{mi}$ nut i następnie analizie chromatograficznej.

\section{Metoda ekstrakcji}

\section{z zastosowaniem kwasu solnego}

Do badanych próbek rozpulchnionych, według procedury opisanej dla kwasu fluorowodorowego, dodano $50 \mu \mathrm{L}$ mieszaniny $12 \mathrm{M} \mathrm{HCl} \mathrm{w}$ wo- 
dzie, poddano działaniom fal ultradźwiękowych przez 60 min i pozostawiono na $24 \mathrm{~h}$ bez dostępu światła. Po tym czasie próblki odwirowano (9000 rpm, $3 \mathrm{~min}$ ). Klarowny zabarwiony roztwór znad osadu odparowano w celu pozbycia się nadmiaru kwasu solnego. Sucha pozostałość rozpuszczono w mieszaninie DMSO/ACN/MeOH $(1 / 1 / 1, v / v / v)$, poddano działaniom fal ultradźwiękowych przez 5 minut i następnie analizie chromatograficznej (rys. 2).

Po dokonaniu efektywnej ekstrakcji substancji barwiących kolejnym etapem procesu ich identyfikacji był dobór odpowiedniej techniki analitycznej oraz optymalizacja parametrów pracy aparatury, umożliwiających rozdzielenie substancji barwiących na poszczególne składniki. Techniki analityczne służące do identyfikacji substancji barwiących muszą zapewnić ich całkowite rozdzielenie, a następnie detekcję tych związków. Z tego też względu rozdzielenie substancji barwiących przeprowadzone zostało z wykorzystaniem wysokosprawnej chromatografii cieczowej (HPLC) w układzie faz odwróconych z zastosowaniem oktadecylowej fazy stacjonarnej C18. Fazę ruchoma stanowiła mieszanina wody z acetonitrylem (ACN) i metanolem $(\mathrm{MeOH})$ w różnych proporcjach. Dodatkiem do fazy ruchomej, zwiększającym rozdzielczość układu chromatograficznego, był 0.1\% wodny roztwór kwasu mrówkowego. W celu identyfikacji rozdzielonych substancji barwiących zastosowano detekcję UV/vis (DAD) oraz spektrometrię mas (MS). Spektroskopia UV/vis dostarcza informacji w postaci widm elektronowych oraz wartości maksimów absorbcji analizowanych związków, co pozwala na porównanie ich chromoforów z chromoforami substancji wzorcowych. Widma mas są natomiast źródłem danych na temat masy jonów cząsteczkowych i jonów fragmentacyjnych, a zatem umożliwiają ustalenie budowy strukturalnej barwników. Do identyfikacji substancji barwiących zastosowano spektrometr mas wyposażony w analizator kwadrupolowy ze źródłem jonizacji metodą elektrorozpylania (ESI).

Za pomoca techniki HPLC-DAD-MS dokonano identyfikacji szeregu związków organicznych (substancji barwiących) odpowiedzialnych za żółta barwę farb malarskich stosowanych przez Jana Matejkę. Analiza chromatograficzna próbek farb przygotowanych metoda z zastosowaniem kwasu fluorowodorowego i kwasu solnego umożliwiła nie tylko identyfikację substancji barwiących w nich zawartych, ale również pozwoliła na określenie 
biologicznych źródeł surowców barwierskich użytych w owym czasie do produkcji farb artystycznych.

\section{Identyfikacja substancji barwiących w próbce farby Matejko 13}

Próbkę żółtej farby Matejko 13 (opisana przez producenta na etykiecie tuby jako Jaune de Indien) poddano analizie HPLC-DAD-MS po wcześniejszej ekstrakcji metoda z zastosowaniem kwasu fluorowodorowego i kwasu solnego. Wyniki analizy w postaci spektrochromatogramu zidentyfikowanych związków przedstawiono na rysunku 3.

Na podstawie uzyskanych wyników analizy HPLC-DAD-MS udało się zidentyfikować dwa główne składniki obecne w próbce farby Matejko 13: kwas euksantynowy (związek 17, tabela 1) oraz euksanton (związek 18) będący aglikonem kwasu euksantynowego, powstałym najprawdopodobniej na skutek naturalnego zestarzenia się tego barwnika, bądź pod wpływem prowadzenia procesu ekstrakcji. Analiza widm mas oraz UV-vis wykazała, że badanym barwnikiem jest żółcień indyjska (ang. Indian Yellow). W celu potwierdzenia obecności żółcieni indyjskiej w próbce Matejko 13 przeprowadzono syntezę euksantonu i poddano go analizie w tych samych warunkach chromatograficznych. W wyniku eksperymentu uzyskano widmo UV-vis oraz widmo mas, odpowiadające naturalnemu euksantonowi. Na podstawie ich porównania z widmami uzyskanymi podczas analizy próbki farby Matejko 13, potwierdzono obecność żółcieni indyjskiej w historycznej farbie olejnej.

Badania wykazały, że żółcień osadzano na wodorotlenku glinu. Analiza XRF oraz SEM-EDX potwierdza obecność magnezu, z którą kwas euksantynowy tworzy sól. Jony wapnia mogą wskazywać zarówno na sole wapniowe tego kwasu, jak i na kredę stanowiąca prawdopodobnie, obok wodorotlenku glinu, nośnik. Niewykluczone jest też jej użycie jako wypełniacza w postaci drobno zmielonej, co uwidacznia mapa rozkładu pierwiastków (rys. 4). W technice tej dobrze widoczne są również skupienia krzemianowe pochodzące prawdopodobnie z dodatku ziaren drobno zmielonego i oczyszczonego piasku kwarcowego. W próbce stwierdzono ponadto drobne skupienia zawierające żelazo, którego obecność wynika z naturalnych zanieczyszczeń 
nieoczyszczonej krzemionki bądź z zanieczyszczeń samej zoółcieni indyjskiej. Zdjęcia z mikroskopu optycznego uwidaczniaja ciemne struktury włókniste, przypuszczalnie resztki nieprzetrawionego materiału organicznego (rys. 5a), a obrazowanie w SEM-BSE (backscattered elctorones) pod mikroskopem skaningowym, bardzo bogatą topografię powierzchni, za którą jak się wydaje, również odpowiedzialne sa składniki organiczne (rys. 5b). Tego typu zanieczyszczeń nie stwierdzono w innych żółcieniach organicznych, co stanowić może czynnik wspomagający identyfikację bądź wskazywać na niepelne oczyszczenie moczu krów w procesie przygotowywania farby.

Żółcień indyjska jest naturalnym barwnikiem otrzymywanym z moczu krów, które karmione były liśćmi mango. Barwnik ten otrzymywano poprzez odparowanie moczu i wyciskanie suchej pozostałości, która następnie była przemywana i filtrowana. Jako kolor używana była głównie w farbach akwarelowych i temperowych przez holenderskich artystów, a przed końcem XVIII wieku była powszechnie stosowana przez artystów z całej Europy $^{19}$. W roku 1908, ze względów humanitarnych (krowy po kilku miesiącach spożywania liści mango zdychały w cierpieniach), zakazano produkcji tego barwnika, chociaż domniema się, że dopiero w 1921 roku przestał on być komercyjnie dostępny. Żółcień indyjska posiada intensywna, czystą żółtą barwę, jej tekstura jest świetlista i „pylista”. Głównym barwnym związkiem żółcieni jest krystaliczna sól magnezowa lub wapniowa kwasu euksantynowego. De Puyster wzmiankuje o oznaczeniu farb różnej jakości od A do G ze względu na stosunek zawartości kwasu euksantynowego oraz związków magnezu (najlepsze gatunki to odpowiednio 65\% kwasu i 5,35\% związków magnezu). Na drugim biegunie znajdowały się te najgorszej jakości farby z zawartością barwnika około 34\%, mniejszą zawartością magnezu i wyższą zawartością soli wapnia w porównaniu z farbami wyższej jakości. Żółcieni indyjskiej używano przede wszystkim w Indiach zwłaszcza między XVII a XIX wiekiem. Mimo kilku wzmianek o użyciu tych żółcieni na XVII-wiecznych obrazach holenderskich i w XVII-wiecznym malarstwie holenderskim brak jest liczniejszych przykładów stwierdzenia obecności tego typu farb na obiektach. Ze względu na swe kolonie w Indiach,

19 Artists Pigments, op.cit., s. 27. 
Wielka Brytania, poza XVII-wieczną Holandia, była w późniejszym okresie głównym miejscem handlu żółcienią indyjską. Jednym z pierwszych, który w XIX wieku miał jej użyć poza Wyspami Brytyjskimi na kontynencie europejskim, był świadomy technolog, Francuz Bouvier ${ }^{20}$. Żółcień indyjska zidentyfikowana została między innymi $\mathrm{w}$ akwarelowych farbach pochodzących z kolekcji ocalonej po Winslow Homerze. Z dużym prawdopodobieństwem wskazywano na jej obecność w książce z próbkami kolorów firmy Winsor and Newton, w których analiza SEM-EDX wykazała obecność Mg oraz Ca. Niestety samego barwnika nie zidentyfikowano. Akwarele Turnera z lat 1830-1850 zawierały „mieszaninę żółcieni indyjskiej z żółta ochrą”21. W XIX wieku żółcień indyjska była często fałszowana żółcienią chromowa. W przypadku zieleni oliwnej oferowanej przez firmę Winsor \& Newton stosowano mieszaninę żółcieni indyjskiej z umbrą i indygo, natomiast w przypadku olejów jako żółcieni stosowano laki z wyciagu z kory dębu kwercetrynowego mieszanych $z$ błękitem pruskim ${ }^{22}$. W trakcie badań ponad stu XIX-wiecznych obrazów prowadzonych w ramach projektu Nowe pigmenty XIX wieku często stwierdzano obok obecności glinu (wskazującego na nośnik w postaci wodorotlenku glinu) oraz wapnia (sugerującego kredę jako kolejny nośnik), także podwyższoną zawartość magnezu. Z dużym prawdopodobieństwem można traktować żółcienie te jako organiczne ${ }^{23}$, niemniej bez możliwości odróżnienia żółcieni indyjskiej od pozostałych organicznych, bazując jedynie na fakcie nieco wyższej zawartości magnezu.

\section{Identyfikacja substancji barwiących w próbkach farb Matejko 14 i 15}

$\mathrm{Na}$ podstawie analizy HPLC-DAD-MS w próbkach farb oznaczonych jako Matejko 14 i Matejko 15 (papierowe etykiety na tubkach farb zawierały

\footnotetext{
20 R. D. Harley, Artists' Pigments c. 1600-1835, s. 117.

21 J.H.Townesend, L. Carlyle, N. Khandekar, S. Woodcock, Later Nineteenth Century Pigments: Evidence for Additions and Substitutions, „The Conservator” 1995, nr 19, s. 74.

22 Townsend et al., Later Nineteenth Century..., p. 74.

23 Tzn. niezawierające charakterystycznych pierwiastków dla innych żółcieni nieorganicznych jak Fe, Cr, Cd, a zawierających m.in. Al, Ca.
} 
odpowiednio nazwy laque de Rober No 5. i laque de Robert No 6.) udało się zidentyfikować kilkanaście substancji barwiących. Zidentyfikowane związki oznaczono numerami na spektrochromatogramie DAD (rys. 5A i B) oraz wymieniono w tabeli 1 . Dzięki zastosowaniu łagodnej metody ekstrakcji (kwas fluorowodorowy) udało się wyizolować O-glikozydy substancji barwiących: kwercetyny (2), kemferolu (3), ramnetyny (4), ramnocytryny (6 i 9) i ramnazyny (8), zawierające w strukturze 3 jednostki cukrowe oraz O-glikozyd ramnetyny (5), zawierający 2 jednostki cukrowe. Poza licznymi glikozydami zidentyfikowano również aglikony tych substancji barwiących: kemferol (10), ramnetynę (11), ramnazynę i jej izomer (12 i 13). Substancje te pochodzą najprawdopodobniej z ekstraktu z jagód krzewu należącego do rodziny szakłakowatych (Rhamnus) używanego do produkcji Still de Grain $^{24}$. Związki te, poza glikozydem ramnetyny (5), były już wcześniej zidentyfikowane w ekstraktach z jagód pochodzących z gatunków krzewów: Rhamnus saxatilis, Rhamnus catharticus oraz Rhamnus alaternus ${ }^{25}$. Obecność luteoliny (7) i jej glikozydu (1) w obu próbkach wskazuje natomiast na użycie barwnika wyekstrahowanego z rezedy żółtawej (Reseda luteola L ${ }^{26}$. Ponadto, w próbce Matejko $14 \mathrm{w}$ niewielkiej ilości zidentyfikowano związek o masie czasteczkowej 256, oznaczony na spektrochromatogramie DAD (rys. 6A) jako związek nr 19, który odpowiada purpurynie bądź jej izomerowi konstytucyjnemu. Na podstawie uzyskanych wyników stwierdzić można, że próbki farb oznaczone symbolami Matejko 14 i 15 nieznacznie różnią się składem podstawowych substancji barwiących oraz że do ich sporządzenia użyto między innymi mieszaninę ekstraktów uzyskanych z dwóch różnych naturalnych surowców barwierskich: jagód z gatunków krzewu z rodziny (Rhamnus) - szakłaków lub kruszyny i rezedy żółtawej (Reseda luteola L.). Różnica między próbkami obu farb polega na obecności prawdopodobnie purpuryny w próbce Matejko 14, co świadczyć może o dodatku laku po-

\footnotetext{
24 Inne nazwy spotykane w literaturze to także: Jaune d'Avignon, Rhamno lake lub Spincervino Lake.

25 G. Cuoco, C. Mathe, C. Vieillescazes, Liquid chromatographic analysis of flavonol compounds in green fruits of three Rhamnus species used in Stil de grain, „Microchemical Journal” 2014, 115, s. $130-137$.

26 C. Moiteiro, H. Gaspar, A. I. Rodrigues, J.F. Lopez, V. Carnide, HPLC quantification of dye flavonoids in Reseda luteola L. from Portugal, „J. Sep.Sci.” 2008, 31, s. 3683-3687.
} 
zyskiwanego z korzeni roślin marzanowatych. Przypuszcza się, że lakiem tym jest purpuryna Koppa (ang. Kopp's purpurin), ponieważ poza purpuryną nie zidentyfikowano innych substancji barwiących. Purpuryna Koppa ze względu na technikę jej produkcji zawiera przede wszystkim duże ilości purpuryny oraz pseudopurpuryny ${ }^{27}$. $\mathrm{Na}$ spektrochromatogramach DAD próbek farb Matejko 14 (rys. 6A) i Matejko 15 (rys. 6B) widać trzy intensywne piki oznaczone znakiem zapytania (?). Ze względu na niską jonizację tych związków nie udało się ich zidentyfikować. Niemniej jednak ich obecność świadczyć może o występowaniu dodatkowych źródeł barwierskich w obu próbkach. Intensywności pików w obu próbkach różnią się między sobą, co najprawdopodobniej może być kolejną przyczyną różnicy w intensywności barwy obu żółcieni.

Badania wykazały, że żółcień organiczną z próbki farby Matejko 14 osadzano na wodorotlenku glinu i kredzie. Zarówno jony potasu, jak i siarki stanowić mogą ślad po sposobie ekstrakcji i warunkach osadzania barwnika na nośnikach z wykorzystaniem różnego typu kwasowych i zasadowych substancji. Na obrazie uzyskanym w skaningowym mikroskopie elektronowym (SEM) stwierdzono również skupienia krzemianowe pochodzące prawdopodobnie $z$ dodatku ziaren drobno zmielonego i oczyszczonego piasku kwarcowego. Obraz powierzchni próbki zarejestrowany detektorem BSE wykazuje duża jednorodność. Próbka zwiera ponadto magnez, ale w znacznie mniejszych ilościach niż w żółcieni indyjskiej z próbki farby Matejko 13. Stwierdzone jony cynku wskazuja przypuszczalnie na niewielkie domieszki bieli cynkowej, dodawanej jako nieco rozjaśniający wypełniacz.

W przypadku próbki Matejko 15 nośnik stanowi również wodorotlenek glinu oraz kreda, brak jest natomiast domieszek bieli cynkowej. W większej ilości występuja jony siarki i potasu, a wypełniacz stanowi, analogicznie jak dla próbki Matejko 14, drobny kwarcowy piasek.

27 R. Chenciner, Madder red. A bistory of luxury and trade, Abingdon 2000, s. 169-170 
Tabela 1. Zbiorcze zestawienie substancji barwiących zidentyfikowanych w próbkach żóltych farb Jana Matejki oznaczonych numerami Matejko 13, 14, 15 i 16, ze wskazaniem surowca barwierskiego

\begin{tabular}{|c|c|c|c|}
\hline Nr związku & Nazwa substancji & $\begin{array}{l}\text { Jon pseudomolekularny } \\
{[\mathrm{M}-\mathrm{H}]^{-}}\end{array}$ & Surowiec barwierski \\
\hline 1 & glikozyd luteoliny & 609 & Rezeda żółtawa (Reseda luteola L.) \\
\hline 2 & glikozyd kwercetyny & 755 & Jagody krzewu z rodziny (Rhamnus) \\
\hline 3 & glikozyd kemferolu & 739 & Jagody krzewu z rodziny (Rhamnus) \\
\hline 4 & glikozyd ramnetyny (ksantoramnina) & 769 & Jagody krzewu z rodziny (Rhamnus) \\
\hline 5 & izomer glikozydu ramnetyny* & 623 & Jagody krzewu z rodziny (Rhamnus) \\
\hline 5 & glikozyd ramnetyny* & 623 & Jagody krzewu z rodziny (Rhamnus) \\
\hline 6 & glikozyd ramnocytryny & 753 & Jagody krzewu z rodziny (Rhamnus) \\
\hline 7 & luteolina & 285 & Rezeda żółtawa (Reseda luteola L.) \\
\hline 8 & glikozyd ramnazyny & 783 & Jagody krzewu z rodziny (Rhamnus) \\
\hline 9 & glikozyd ramnocytryny & 795 & Jagody krzewu z rodziny (Rhamnus) \\
\hline 10 & kemferol & 285 & Jagody krzewu z rodziny (Rhamnus) \\
\hline 11 & ramnetyna & 315 & Jagody krzewu z rodziny (Rhamnus) \\
\hline 12 & izomer ramnazyny * & 329 & Jagody krzewu z rodziny (Rhamnus) \\
\hline 13 & ramnazyna * & 329 & Jagody krzewu z rodziny (Rhamnus) \\
\hline 14 & emodyna & 269 & Jagody krzewu z rodziny (Rhamnus) \\
\hline 15 & rutyna (glikozyd kwercetyny) & 609 & Jagody krzewu z rodziny (Rhamnus) \\
\hline 16 & ramnozyd kwercetyny & 447 & Jagody krzewu z rodziny (Rhamnus) \\
\hline 17 & kwas euksantynowy & 403 & Mocz krów (żółcień indyjska) \\
\hline 18 & euksanton & 227 & Mocz krów (żółcień indyjska) \\
\hline 19 & purpuryna & 255 & $\begin{array}{l}\text { Ekstrahowany z krapu z marzanny bar- } \\
\text { wierskiej - purpuryna Kopp'a? }\end{array}$ \\
\hline
\end{tabular}

* izomery konstytucyjne

\section{Identyfikacja substancji barwiących w próbce farby Matejko 16}

Na podstawie analizy HPLC-DAD-MS (rys. 7) w próbce Matejko 16 (oznaczonej na etykiecie nazwa Still de Grain) zidentyfikowano kilkanaście substancji barwiących pochodzących również z ekstraktu uzyskanego z jagód krzewu z rodziny szakłakowatych (Rhamnus). Poza substancjami barwiącymi 
oznaczonymi w tabeli 1 numerami 2-6, 10-13, obecnymi w próbkach farb Matejko 14 i 15, w próbce Matejko 16 zidentyfikowano dodatkowo: emodynę (14) oraz ramnozyd kwercetyny (16). Obecność tych związków w jagodach (Rhamnus) potwierdza w swoich badaniach Ferreira ${ }^{28}$. Ponadto, w próbce farby Matejko 16 udało się zidentyfikować również rutynę (glikozyd kwercetyny) (związek 15) oraz izomer glikozydu ramnetyny zawierający 2 jednostki cukrowe (związek 5'). Substancje te jak dotąd nie zostały wcześniej wyizolowane i zidentyfikowane w ekstrakcie z jagód (Rhammus). Być może wskazuja one na dodatek wyciagu $z$ innego surowca naturalnego lub nieco inne metody ekstrakcji, która nie naruszyła pierwotnej struktury składników ${ }^{29}$.

Próbka Matejko 16 osadzana była na wodorotlenku glinu, na co wskazuje mapa rozkładu pierwiastków wykonana techniką SEM-EDX. W analogicznych obszarach obecna jest również siarka (rys. 8). Oprócz pierwiastków obecnych w poprzednich próbkach zidentyfikowano dodatkowo chlor, a także znaczne ilości fosforu.

Still de Grain to niezbyt precyzyjna nazwa barwnika obejmującego szerokie spektrum substancji wchodzących w jego skład. Większość źródeł wskazuje na substancje barwne pozyskiwane z niedojrzałych owoców krzewów z rodziny szakłaków, pochodzących z Bliskiego Wschodu. Inna nazwa tego barwnika odnosi się do laku z jagód perskich (ang. persian berries), jako surowca wyjściowego. Gatunki europejskie były znane także pod nazwą jagód awiniońskich, bądź szerzej - francuskich ${ }^{30}$. Wszystkie gatunki szakłaków (m.in Rhamnus cathartica L., r. saxatilis Jacq., r. tinctoria Waldst. \& Kit., r. infectoria L., r. lycioides L., r. amygdalina Desf., r. petiolaris Boiss. \& Bal., r. alaternus L.) zawierają ramnetynę jako główną substancję barwiąca. Kolejne, w zależności od gatunku rośliny, to kwercetyna, kemferol i inne ${ }^{31}$.

28 Patrz przypis nr 9.

29 Dla obrazu Aleksandra Gierymskiego Staruszka czuwajaca pray zpmłokach II (po 1890) w próbce koloru brązowego stwierdzono przypuszczalnie (ze znakiem zapytania) emodynę oraz rutynę osadzone na wodorotlenku węgla i wstępnie przypisano je do źródła roślinnego w postaci przedstawicieli rodziny Rheum (rabarbar, rzewień) lub Rhumex (szczawie), zaznaczając niemożliwość pewnych rozstrzygnięć, s. 115.

30 R.D. Harley, op.cit., s. 109.

31 Hofenk de Graff, op.cit., s. 194-195, Hopliński twierdzi, że still de grain otrzymywano z rezedy, J. Hopliński, Farby i materiały malrskie, Wrocław 1990, s. 178. 
W XIX wieku sytuacja ulega dalszej komplikacji. Według Bergera - dostawcy farb, w skład tak zwanego „English pink” wchodziła mieszanina wyciagu z kory drzewa fustykowego Maclura tinctoria (ang. Old fustic, Dyer's mullberry) oraz kory dębu kwercytrynowego, osadzanych na kredzie. Natomiast „yellow berries” używano w produkcji „Dutch pink” do $1815^{32}$, a z kolei „Italian pink” otrzymywano z żółtych jagód osadzanych na wodorotlenku glinu. Farba „Spanish yellow” miała być otrzymywana z rezedy zawierającej luteolinę oraz apigeninę, jako główne substancje barwiące ${ }^{33}$. Biorąc pod uwagę, iż w przypadku przemysłu tekstylnego, który często był pierwowzorem dla barwników stosowanych później w farbach, rezeda była często stosowana $\mathrm{z}$ krokoszem barwierskim (Serratula tinctoria L.) oraz z janowcem barwierskim (Genista tinctoria L.), które obok luteoliny zawierały także genistynę, a w przypadku janowca kwercetynę i przypuszczalnie glikozyd luteoliny. Możliwe mieszaniny tych ekstraktów przedstawiają obraz jeszcze bardziej złożony. W drugiej połowie XIX wieku coraz częściej narastała tendencja do fałszowania farb i zastępowania ich tańszymi zamiennikami. Przykładowo, analiza TLC próbek barwników firmy Winsor \& Newton oznaczonych jako „Brown pink” oraz „Italian pink” wykazała obecność bliżej niesprecyzowanych flawonoidów. Ponadto farby tego typu były też często fałszowane wyciagiem z kory dębu kwercytrynowego ${ }^{34}$. Obecność substancji barwiących pochodzących z wyciagu z jagód perskich potwierdzono w XIX-wiecznej kolekcji pigmentów, która przebadana została przez Richtera i Härlin ${ }^{35}$. Poza opracowaniem dotyczącym materiałów malarskich stosowanych przez Aleksandra Gierymskiego brak jest informacji o identyfikacji tego typu barwników na obrazach ${ }^{36}$.

Struktury chemiczne organicznych substancji barwiących zidentyfikowanych w próbkach źółtych farb z tubek Jana Matejki przedstawione sa na rysunku 9, natomiast zestawienie zidentyfikowanych materiałów włącznie z nieorganicznymi nośnikami i wypełniaczami farb, stwierdzonymi na

32 Harley, op.cit., s. 112.

33 Hofenk de Graaf, op.cit., s. 215.

34 Townsend et al., Later Nineteenth Century..., s. 73.

35 E. L. Richter, H. Härlin, A nineteenth century collection of pigments and painting materials, Studies in Conservation, 19 (1974), s. 76-82

36 E. Dolezyńska-Sewerniak, Materiały malarskie..., s. 510-511. 
podstawie analizy XRF oraz SEM-EDX w tabeli nr 2. Różnice w składzie pierwiastkowym pomiędzy poszczególnymi farbami stwierdzone na podstawie badań XRF przedstawia rys. 10.

\section{Podsumowanie}

Pełna identyfikacja substancji barwiących obecnych w oryginalnych farbach artystycznych XIX wiecznych malarzy pozwoli na stworzenie bazy danych organicznych barwników stosowanych w owym czasie do produkcji farb. Wspomoże orzekanie o autentyczności i datowanie oraz uprości interpretację źródeł w postaci historycznych katalogów farb. Identyfikacja produktów rozkładu barwników przydatna będzie w określeniu aktualnego stanu farb i zmian, jakie zaszły w wyniku procesów starzenia się barwników. Tak uzyskane dane pozwalaja również na pełniejsze rozumienie analiz pomiarów wykonanych dla obrazów, na których kolor najczęściej występuje w mieszaninie i widmo uzyskane do interpretacji jest dużo bardziej złożone.

Powyższe badania zilustrowały złożoność podjętej problematyki i wyzwania na tym niezwykle ciekawym, a ciagle jeszcze słabo rozpoznanym obszarze badawczym.

Badania składu pierwiastkowego nieorganicznej części laków w postaci nośników i wypełniaczy wykonanych za pomoca metod XRF oraz SEM-EDX sfinansowano z grantu NCN „Nowe Pigmenty XIX wieku”, 2012/05/D/HS2/03385. 
Tabela 2. Charakterystyka farb na podstawie przeprowadzonych badań HPLC-DAD, SEM-EDX oraz XRF

\begin{tabular}{|c|c|c|c|c|}
\hline $\mathrm{Nr}$ & zdjęcie & $\begin{array}{c}\text { Nazwa } \\
\text { wg etykiety }\end{array}$ & $\begin{array}{l}\text { Stwierdzone pierwiastki } \\
\text { (SEM-EDX, poniżej XRF) }\end{array}$ & Charakterystyka farby \\
\hline 13 & & Jaune de Indien & $\begin{array}{l}\mathrm{Mg}, \mathrm{Ca}, \mathrm{Al} ., \mathrm{Si} \\
\underline{\mathrm{Ca}}, \mathrm{Fe}, \mathrm{As}, \mathrm{Sn}\end{array}$ & $\begin{array}{l}\text { Żótcień indyjska (sole magnezowe i wapnio- } \\
\text { we kwasu euksantynowego) osadzana na wo- } \\
\text { dorotlenku glinu i zawierająca ziarna piasku } \\
\text { kwarcowego }\end{array}$ \\
\hline 14 & & $\begin{array}{l}\text { laque de Robert } \\
\text { No } 5 . \\
\text { (jasna) }\end{array}$ & $\begin{array}{c}\text { Ca, Al, S, K, Si, } \\
\text { Mg śladowo Fe, Zn } \\
\text { Ca, S, P, Fe, Pb, } \\
\text { Mn, Zn, Sr, Sn }\end{array}$ & $\begin{array}{l}\text { Żółcień na bazie niezidentyfikowanego barw- } \\
\text { nika, prawdopodobnie syntetycznego, wycią- } \\
\text { gu z niedojrzałych owoców rośliny z rodziny } \\
\text { szakłaków (zwany Still de Grain) i wyciągu } \\
\text { z rezedy żóttawej z dodatkiem purpuryny po- } \\
\text { chodzacej z ekstraktu korzenia marzanny bar- } \\
\text { wierskiej - prawdopodobnie w postaci tzw. } \\
\text { purpuryny Kopp’a. Barwniki osadzane na wo- } \\
\text { dorotlenku glinu i kredzie oraz prawdopodob- } \\
\text { nie związkach cyny, z wypełniaczem w postaci } \\
\text { piasku kwarcowego, bieli ołowiowej i przy- } \\
\text { puszczalnie śladowej ilości bieli cynkowej. }\end{array}$ \\
\hline 15 & & $\begin{array}{l}\text { laque de Robert } \\
\text { No } 6 . \\
\text { (ciemna) }\end{array}$ & $\begin{array}{l}\mathrm{Ca}, \mathrm{S}, \mathrm{Al}, \mathrm{K}, \mathrm{Si}, \mathrm{Mg} \\
\mathrm{Ca}, \mathrm{S}, \mathrm{P}, \mathrm{Fe}, \mathrm{Cu} \\
\mathrm{Mn}, \mathrm{Zn}, \mathrm{Sr}, \mathrm{Sn}\end{array}$ & $\begin{array}{l}\text { Żółcień na bazie niezidentyfikowanego barw- } \\
\text { nika, prawdopodobnie syntetycznego, wycią- } \\
\text { gu z niedojrzałych owoców rośliny z rodziny } \\
\text { szakłaków (Still de Grain), wyciągu z rezedy } \\
\text { żóttawej. Barwniki osadzane na kredzie, wo- } \\
\text { dorotlenku glinu, oraz prawdopodobnie związ- } \\
\text { kach cyny, z wypełniaczem w postaci piasku } \\
\text { kwarcowego. Miedź być może można wiązá ć } \\
\text { z siarczanem miedzi używanym przy pozyski- } \\
\text { waniu barwnika }\end{array}$ \\
\hline 16 & & Still de Grain & $\begin{array}{l}\text { Al, Ca, Si, K, Cl, } \\
\text { S, P, Mg, Na } \\
\text { Ca, S, As, Fe, Mn, } \\
\text { Zn, Sr, Sn, Cu }\end{array}$ & $\begin{array}{l}\text { Żółcień na bazie wyciągu z niedojrzałych } \\
\text { owoców rośliny z rodziny szakłaków (Still } \\
\text { de Grain). Barwniki osadzone na wodorotlen- } \\
\text { ku glinu i kredzie z wypełniaczem w postaci } \\
\text { piasku kwarcowego. } \\
\text { Miedź być może można wiązać z siarczanem } \\
\text { miedzi używanym przy pozyskiwaniu barwnika }\end{array}$ \\
\hline
\end{tabular}




\section{Summary}

\section{Yellow organic dyes in the 19th century paints of Jan Matejko. Identification of dyestuffs, carriers and fillers}

Natural organic dyes can be found in many objects of cultural heritage. Identification of coloring substances present in historical paints provides relevant information for a wide range of specialists involved in art science. Determination of the composition of paints allows application of appropriate procedures for restoration and conservation of historical works of art. This information enables treatment in accordance with the ideological and esthetic decisions of the authors. The complexity of the chemical composition of art paints, which, apart from organic dyes can also include inorganic pigments, binders and other additives, hinders isolation and identification of its individual components. Nowadays, there are several analytical techniques and methods for extraction and identification of organic dyes, each of them has its limitations, however. For that reason, the development of the universal methodology for the analysis of colorant composition in art paints remains a challenge for chemists. In present work, an analytical protocol for identification of yellow dyes using reversed phase liquid chromatographymass spectrometry with atmospheric pressure electrospray ionization (LC-ESI/ /MS) is presented. The developed method was successfully applied to identification of the main components of Indian Yellow, weld (Reseda luteola L.), buckethorn berries (Rhamnus) and madder lake (madder plant's root) extracts, in the historical oil paints from tubes of Richard Ainès company, formerly Mulard, owned before him by recognizable French art materials supplier Eduard. The recognition of paints composition was broadened by identification of non organic compounds - carriers of the dye: aluminum hydroxide, tin chloride, chalk, as well as filler like silica and or lead white. Researched samples of painting materials belonged to 19th century famous Polish painter Jan Matejko (1839-1893) and will be very helpful in understanding paintings of him and of his contemporaries. 
<smiles>O=C(O)[C@H]1OC[C@H](Oc2ccc3oc4cccc(O)c4c(=O)c3c2)[C@@H](O)[C@@H]1O</smiles>

glikozyd

substancji barwiącej<smiles>C[14CH2][14CH2]O</smiles>

aglikon substancji barwiącej

Rys. 1. Struktura chemiczna przykładowej substancji barwiącej występującej w formie glikozydu i aglikonu

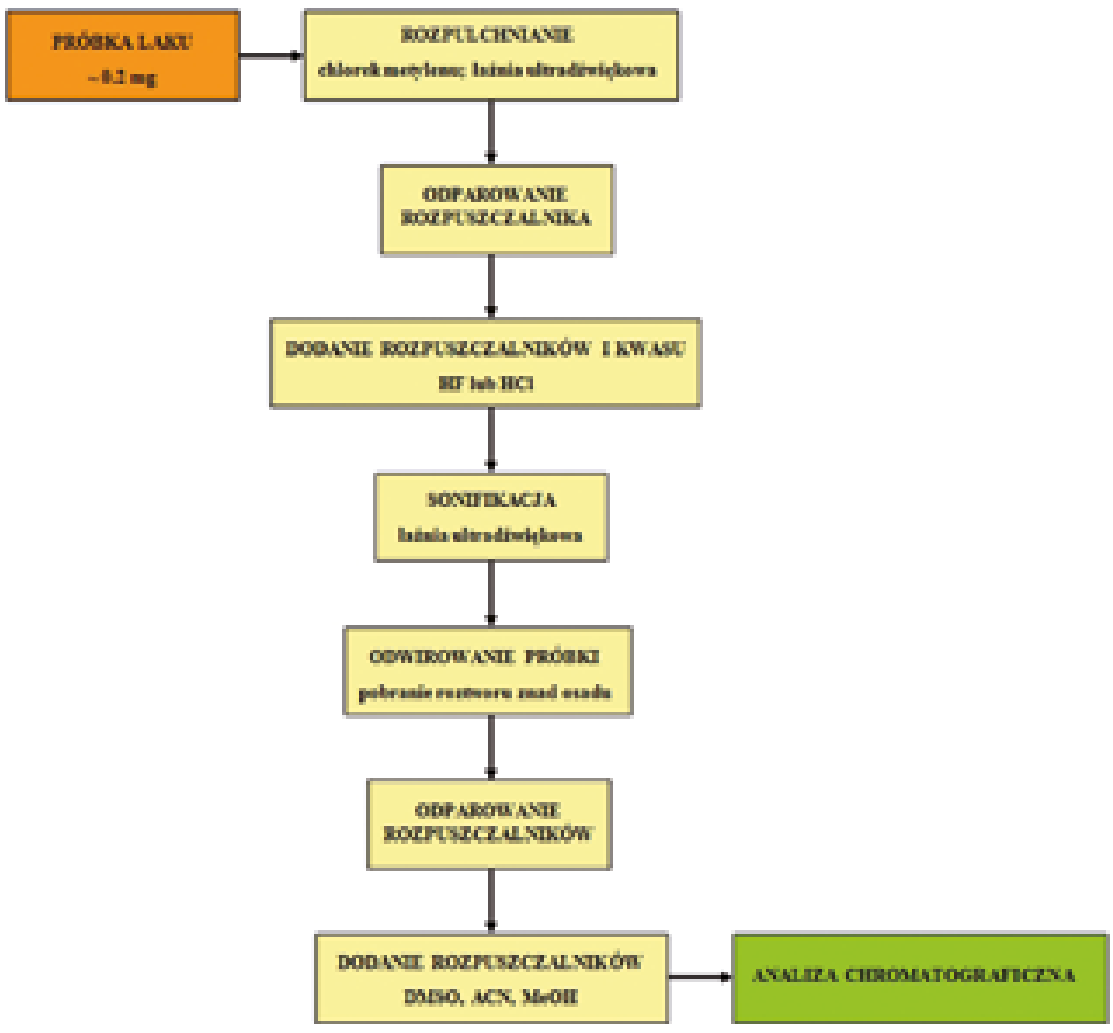

Rys. 2. Schemat ideowy kolejnych etapów ekstrakcji substancji barwiących ze spoiwa malarskiego 


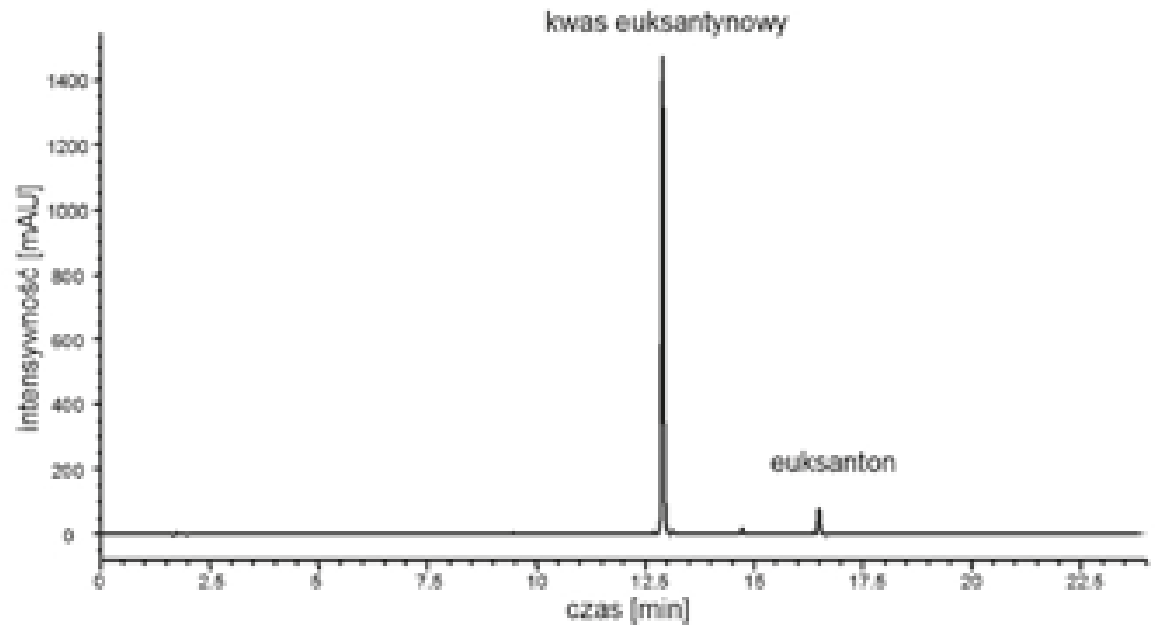

Rys. 3. Spektrochromatogram HPLC-DAD ekstraktu próbki farby Matejko 13, wykonanej z zastosowaniem kwasu fluorowodorowego
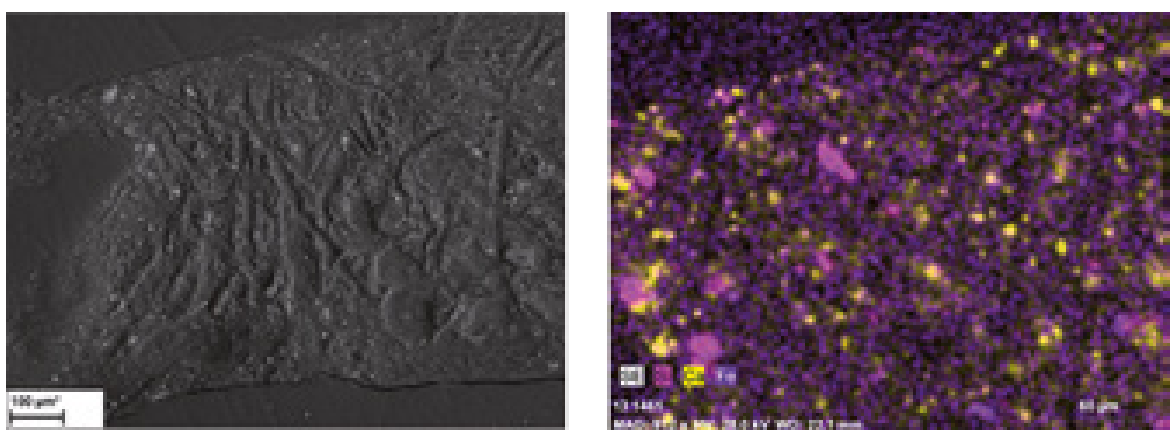

Rys. 4. Obraz próbki farby Matejko 13 (Jaune de Indien) w świetle elektronów odbitych SEM-BSE, bogata topografia powierzchni związana z organicznymi strukturami włóknistymi oraz mapa rozkładu pierwiastków w tejże próbce, widoczne ziarna piasku kwarcowego, skupienia wapnia oraz żelaza 


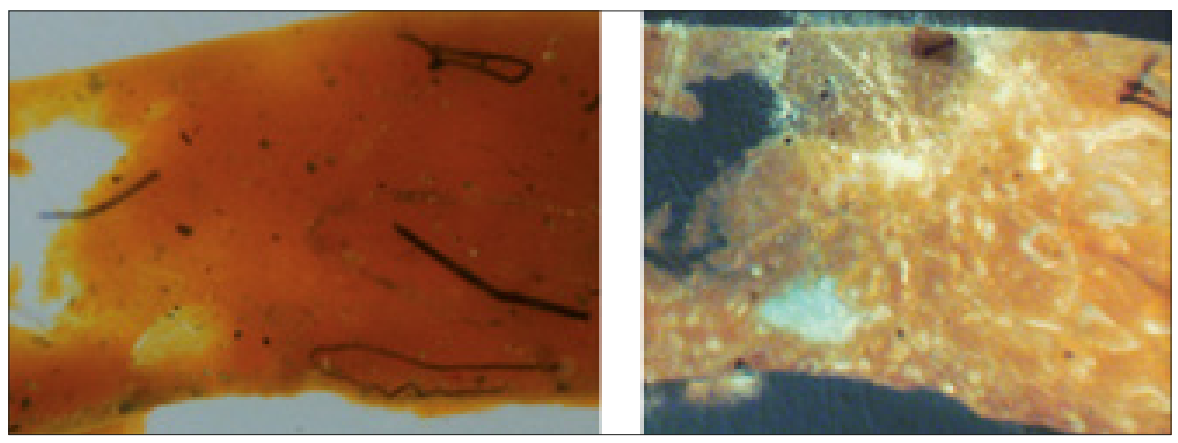

Rys. 5. a i b. Zdjęcie mikroskopowe próbli Matejko 13 (Jaune de Indien), 200 x w świetle Vis oraz UV, widoczne organiczne struktury włókniste, fot. T. Kozielec 

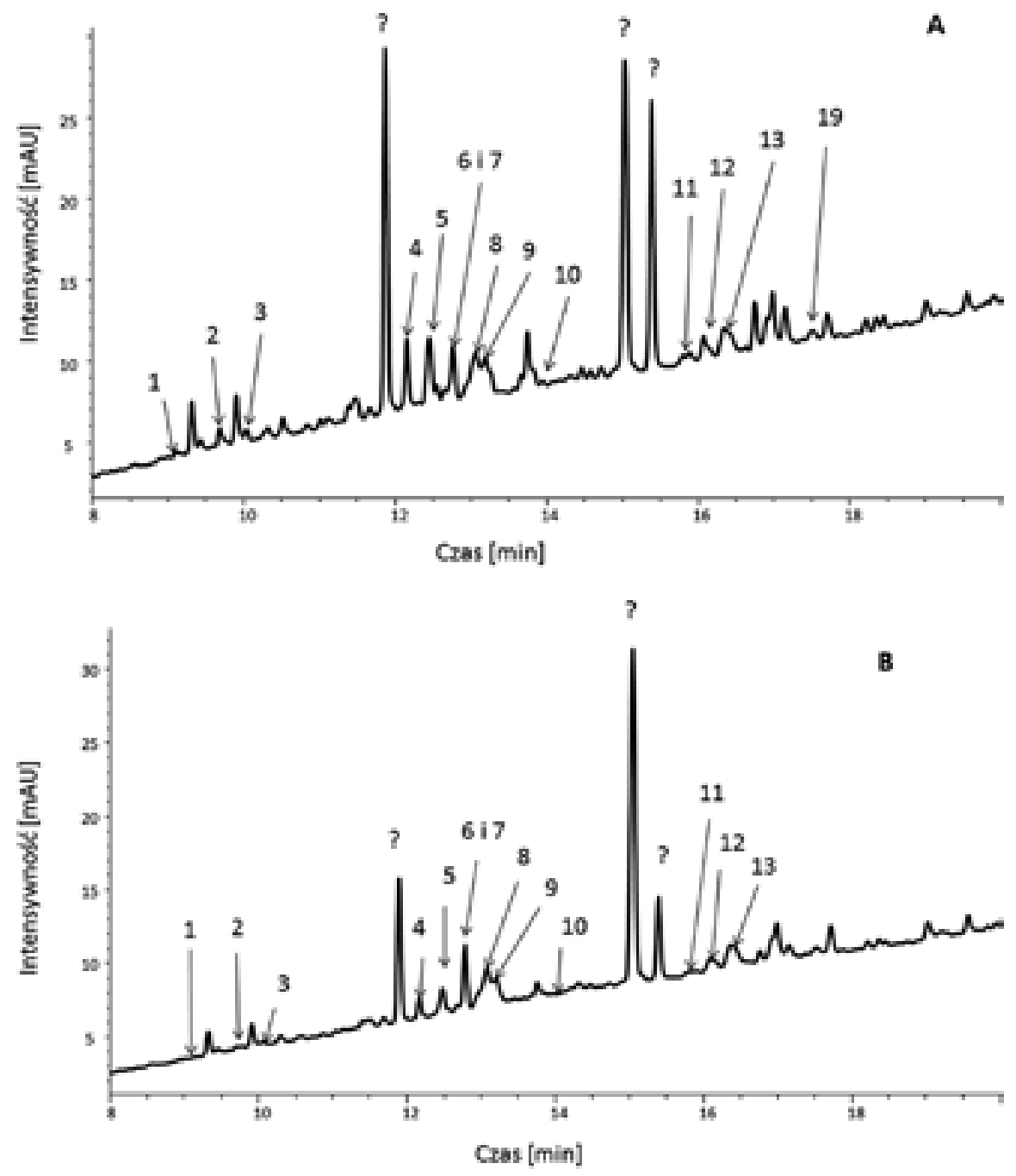

Rys. 6. Spektrochromatogramy HPLC-DAD ekstraktu próbek farb: A) Matejko 14 i B) Matejko 15 wykonanych z zastosowaniem kwasu fluorowodorowego. Zidentyfikowane związki wymieniono w tabeli 1 


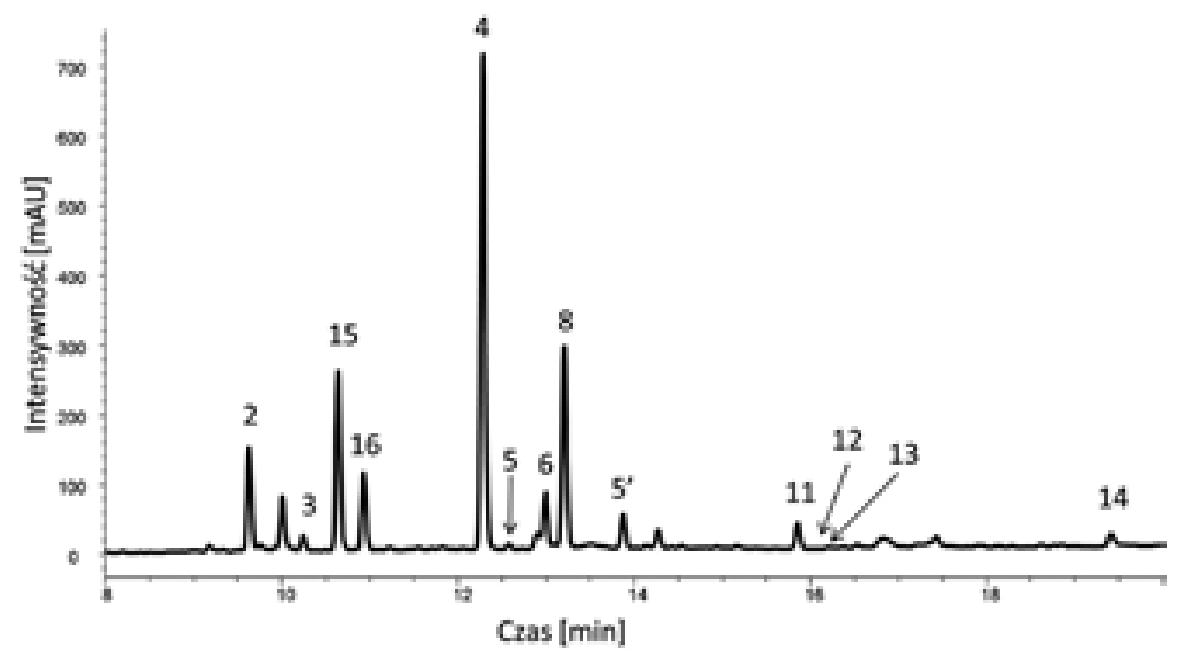

Rys. 7. Spektrochromatogram HPLC-DAD ekstraktu próbki farby Matejko 16, wykonanej z zastosowaniem kwasu fluorowodorowego. Zidentyfikowane związki wymieniono w tabeli 1 
[312]
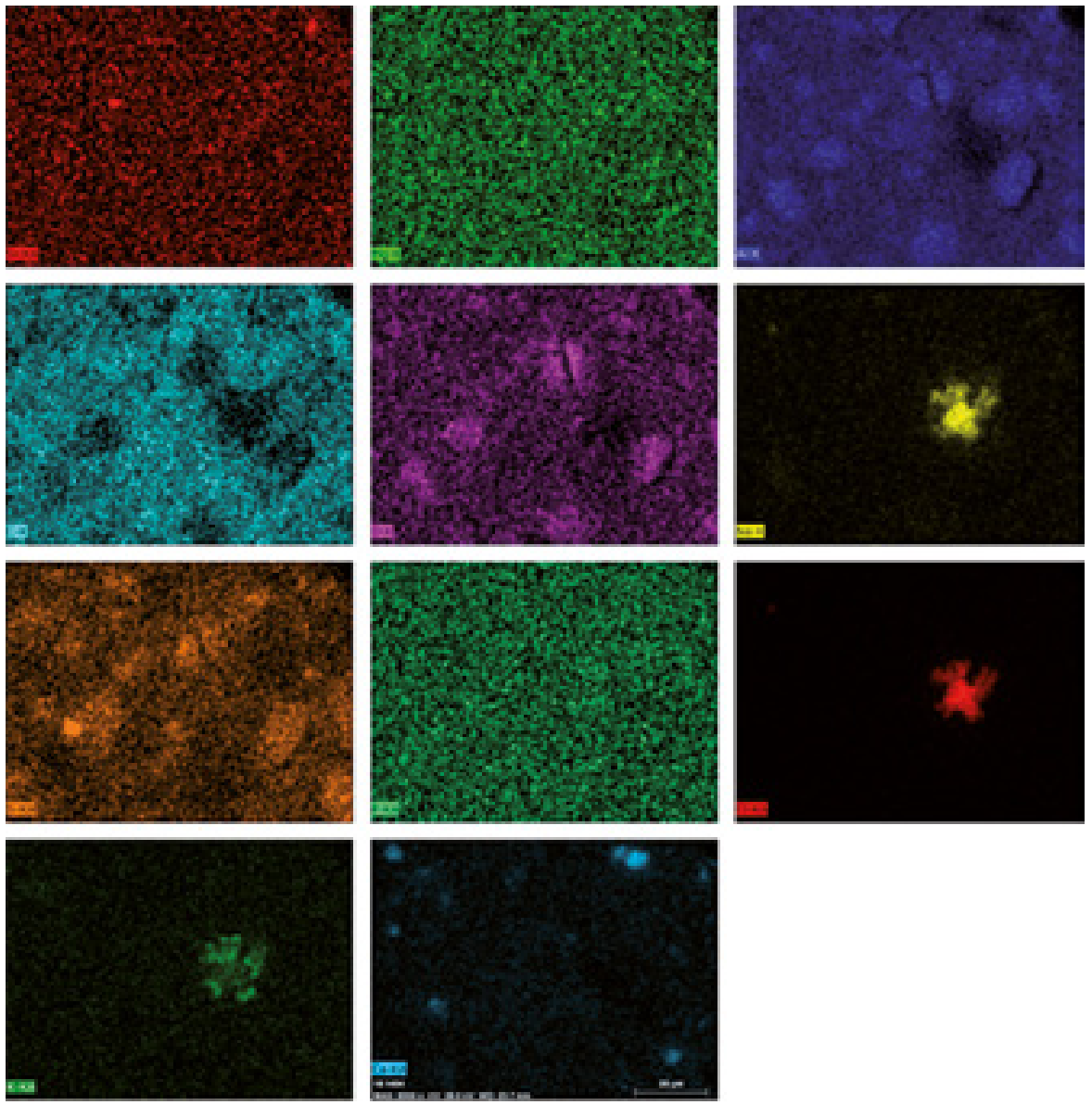

Rys. 8. Mapy rozkładu poszczególnych pierwiastków w próbce farby Matejko 16 na podstawie badań SEM-EDX 

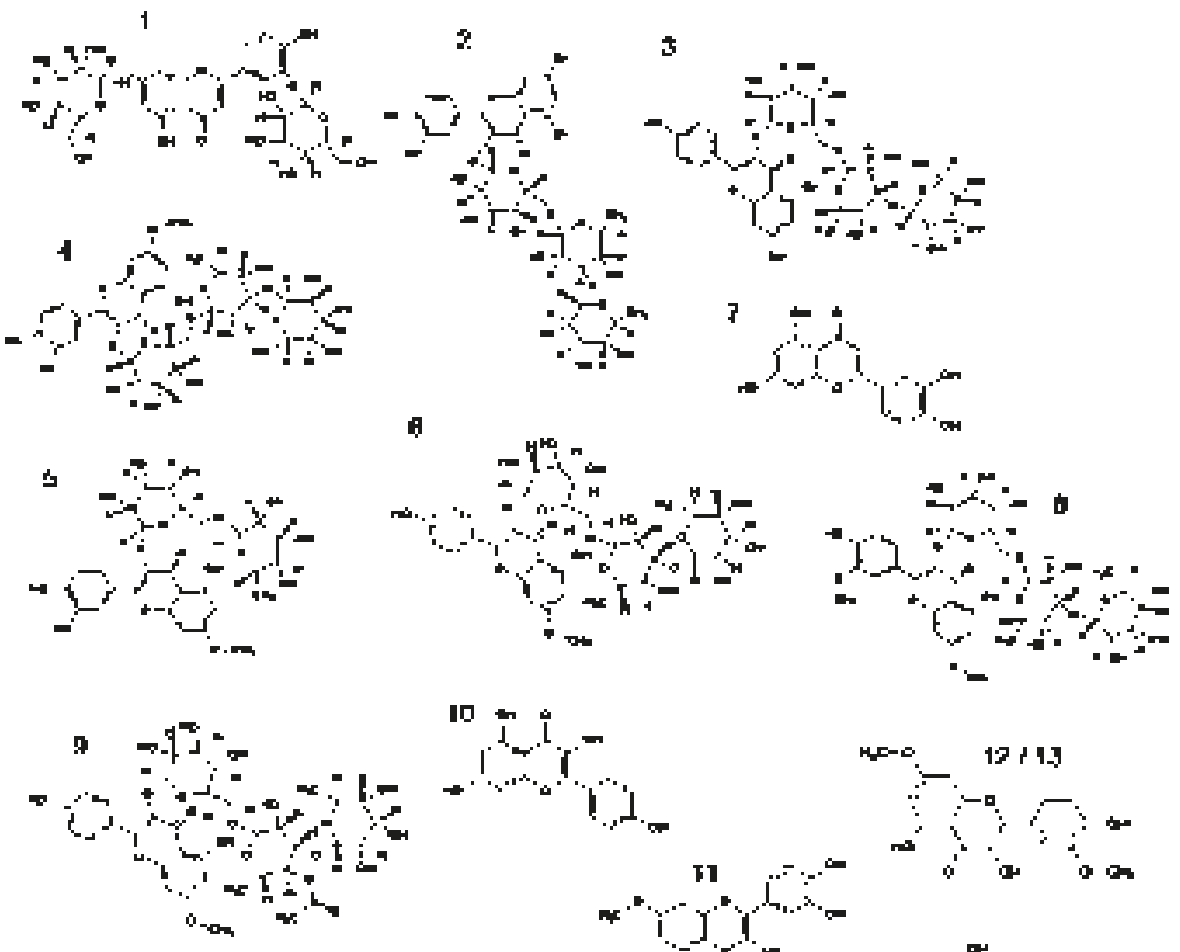

$1+$
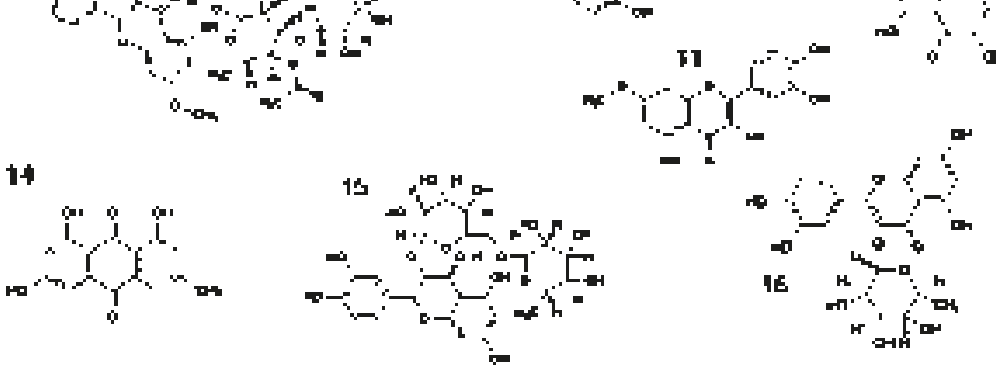

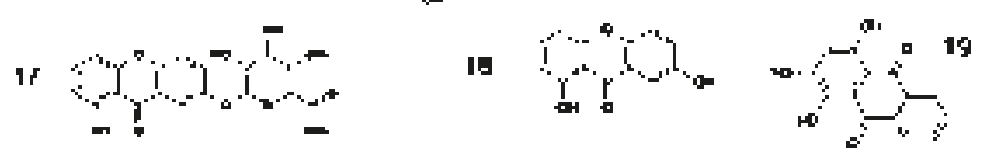

Rys. 9. Struktury chemiczne substancji barwiących zidentyfikowane w próbkach farb Matejko $13,14,15$ i 16 


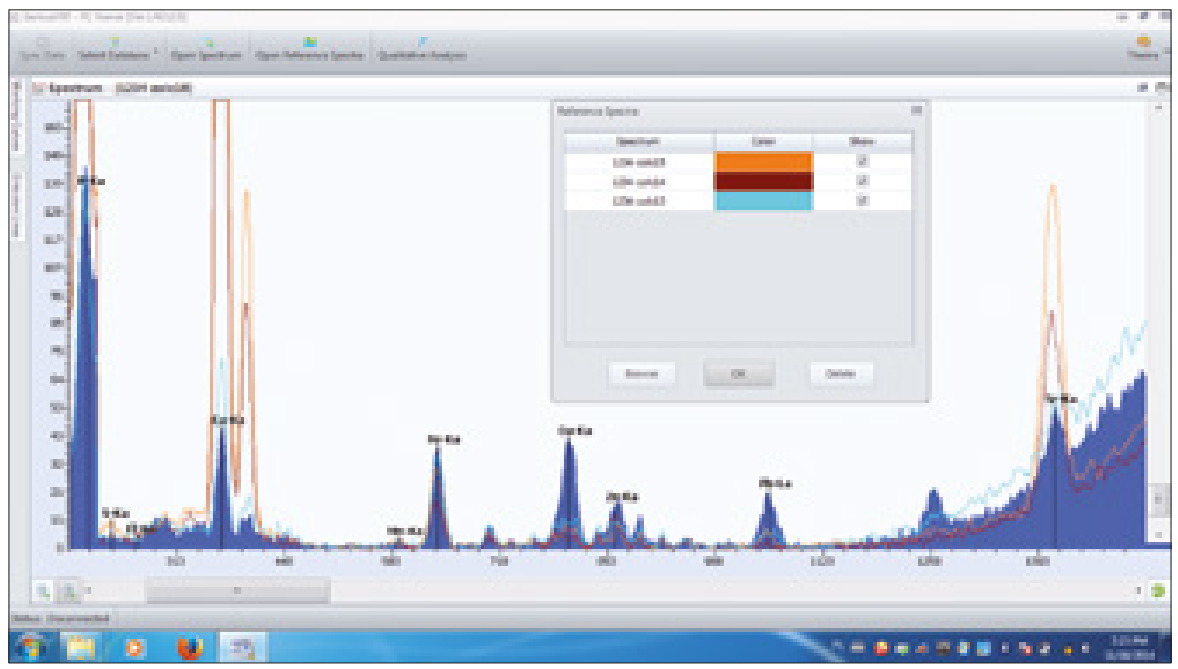

Rys. 10. Zestawienie widm uzyskanych w analizie wykonanej techniką XRF próbek farb: Matejko 16 (Still de Grain) - niebieskie wypełnienie, Matejko 13 (Jaune de Indien) - linia koloru jasnoniebieskiego, Matejko 14 (Laque de Robert No 5) - linia koloru ciemnoczerwonego oraz Matejko 15 (Laque de Robert No o) - linia koloru pomarańczowego, Próbkę nr 16 wyróżnia obecność $\mathrm{Cu}$ (prawdopodobnie z siarczanu miedzi) oraz $\mathrm{Pb}$ (z bieli ołowiowej bądź siarczanu ołowiu), a także w porównaniu z pozostałymi znacznie mniejsze ilości Ca oraz P w składzie laku 